\title{
Guide til Danmarks Bjerge
}

Af pens. lektor Søren Rasmussen, Geologisk Institut, Aarhus Universitet

I en ny bog om Danmarks "bjerge" fører den norske forfatter Roger Pihl læserne ind i danske fjeldekspeditioner. Udover at berette om lokaliteternes beskaffenhed omtaler forfatteren bl.a. også folkesagn og historiske aspekter.

Den norske forfatter og fjeldfører, Roger Pihl har af fået den pudsige ide at udarbejde en guide til de højeste toppe i det danske "højfjeld". Udgangspunktet for guiden har været - på grundlag af Kort- og Matrikelstyrelsens topografiske kort i målestoksforholdet 1:100.000-at lokalisere toppe og højdedrag højere end $100 \mathrm{~m}$ i DK. Herudover har det været et kriterium, at lokaliteterne for at komme med i guiden også skulle have et egennavn. Det er blevet til 184 lokaliteter.

\section{Frederik VII's Høj i Vesterskoven}

Et skønsomt udvalg heraf er beskrevet nærmere. 27 i Jylland, 8 på Fyn, 4 på Sjælland, 4 på Møn samt 6 på Bornholm er det blevet til. Det er der kommet en letlæst og ganske underholdende bog på 348 sider ud af, som udover at være en turguide også beskriver de forskellige lokaliteters topografiske forhold, samt hvad der knytter sig til disse af kulturel og historisk art. De enkelte lokalite-

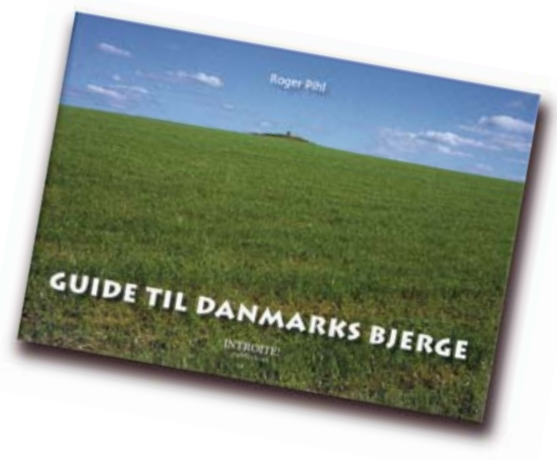

og hans forhold til grevinde Danner, og i omtalen af Tihøje og Trehøje på Skovbjerg Bakkeø, får vi hele Dalgas' liv og levned beskrevet. Også hele historien om, hvad der i tidens løb har været anset som Danmarks højeste punkt, kan man finde i bogen (opdateret med de seneste data om Ejer Møllehøj).

Med hovedvægten på de ovennævnte temaer bliver der kun i grove hovedtræk og langt fra i alle tilfælde redegjort for lokaliteternes geologiske dannelsesforhold. Til gengæld er der så i forbindelse med de enkelte hovedafsnit en anprisning af en lokal kro, hvor man kan finde hvile og restituere sig, inden man igen kaster sig ud i nye udfordringer i de danske bjerge.

ters tilgængelighed beskrives i et malende, vittigt og undertiden også i et underfundigt sprog, og hvor strabadserende op- og nedturene kan være, beskrives med en erfaren fjeldgængers terminologi. Den største udfordring for forfatteren har været bestigningen af Frederik VII's Høj i Vesterskoven ved Silkeborg.

Hertil så i øvrigt omtale af, hvad der forefindes af mindesmærker og geodætiske postamenter, og hvad der er knyttet af folkelige traditioner og folkesagn til stederne, og hvilke forfattere og digtere, der har værdsat og besunget stedernes fortræffelig- og yndigheder etc. Fyldige beskrivelser, som ikke bliver mindre af, at forfatteren har let til digressioner og sidespring, således i forbindelse med Frederik VII's Høj får vi en beretning om kongens mislykkede ægteskaber

\section{Lidt rod i årstal og geografi}

Bogen, der er ukommet på både dansk og norsk, er generøst illustreret med kort og fotos $o g$ forsynet med fyldige referencer. Men man kunne godt have ønsket sig en lidt tættere korrektur, flere årstal er således angivet 100 år forkert, og på et par af kortene er der rod i geografien. Sukkertoppen ved vestenden af Mossø er således blevet placeret på Jyske Ås i Vendsyssel, og Sindbjerg ved Sejs er blevet placeret ved Horsens.

Guide til Danmarks Bjerge af Roger Pihls oversat af Orla Vigsø. Stort format, 500 4-farvebilleder. Indbundet med smudsomslag, 352 sider, 348 kr, 2005. Introite! Publishers, København. ISBN 87-90820-17-7. 